\title{
Effectiveness of Learning with 3D-Lab on Omani Basic Education Students' Achievement, Attitudes and Scientific Thinking
}

\author{
Ali Al Musawi ${ }^{1}$, Abdullah Ambusaidi ${ }^{1}$, Sulaiman Al-Balushi ${ }^{1}$, Mohamed Al-Sinani ${ }^{2}$, Kholoud Al-Balushi ${ }^{2}$ \\ ${ }^{1}$ College of Education, Sultan Qaboos University, Al-Khoidh, Oman \\ ${ }^{2}$ Ministry of Education, Oman \\ Correspondence: Ali Al Musawi, College of Education, Sultan Qaboos University, Al-Khoidh, P.O.Box 32 PC 123, \\ Oman.
}

Received: September 19, 2017

doi:10.11114/jets.v5i11.2743
Accepted: October 19, 2017 Online Published: October 29, 2017

URL: https://doi.org/10.11114/jets.v5i11.2743

\begin{abstract}
This paper aims to measure the effectiveness of the 3DL on Omani students' acquisition of practical abilities and skills. It examines the effectiveness of the 3D-lab in science education and scientific thinking acquisition as part of a national project funded by The Research Council. Four research tools in a Pre-Post Test Control Group Design, findings show statistically significant differences in student achievement in favor of the experimental group. The results show students' attitudes are positive towards using 3D-lab in teaching. Improvements in logical and visual thinking are also observed. The paper then draws conclusions and recommendations.
\end{abstract}

Keywords: 3D-lab, Oman, science education, attitude, basic education, logical thinking, visual thinking

\section{Introduction}

\subsection{The Problem}

The strategies used as part of the traditional school settings have certainly not addressed the educational requirements in this information age. To accomplish the scientific and lifelong learning objectives, we need to implement new methods and techniques taking advantage of the technological developments and innovative practices. Innovative applications have influenced the academic community members and instructional materials and mechanisms. They have become an essential part of the teaching and learning process. For example, science educators can benefit from the use of 3D simulations during their lab work and practical lessons.

The study aims to investigate the effectiveness of the 3DL in teaching science with a set of cognitive variables particularly academic achievement, logical thinking, and visual thinking among fourth graders in the Omani basic education schools. In addition, the study aims to identify advantages and impediments of using 3DL in the Omani basic education schools.

\subsection{Importance of the Problem}

This study is important specifically for the Omani educational system because the students need to get practical and mental skills in using 3DL in their science lessons and their teachers need to be encouraged to apply new educational technologies in their daily practical work. They must build up the scientific thinking skills and procedures among students using active electronic and interactive tools. The study inspires them to find out about the effectiveness of these lab tools and develop inquiry based learning their science lessons. It is equally important to develop students' attitudes toward science and lab work in basic education in Oman.

\subsection{Relevant Scholarship}

Integrating innovations and technologies in teaching and learning is no longer an extra tool in a classroom. It has become a prerequisite for the foundation of an effective educational infrastructure as it provides a dynamic and lively experience for learners. For example, e-Learning has become indispensable in people's lives and applications, since mobile, portable, and virtual learning have started (Sharples, Amedillo, Milrad \& Vavoula, 2007). The utilization of these technologies infers extraordinary impact on schools, students and science. They allow controlling situations that are hard to experiment in old-fashioned classroom settings and implementing numerous unsafe experiments through 
virtual reality. We will now survey research accounts on ideas, definitions, implications, types, and impediments of 3D-labs (later, 3DL).

\subsubsection{Definition Objectives of 3DL}

Science education is strictly related to experimental practices and practical work. Current literature approves the vital role of experimentation in broadening the learners' dynamic involvement in the learning process along with the idea of developing their diverse aptitudes and shaping their positive dispositions towards science education (ICSU, 2011). Laboratories designers have concentrated their thoughts to use computer applications that produces a safe, active, and collaborative learning setting and simulates realistic 3DL. This lab may be defined as "one where the student interacts with an experiment or activity which is intrinsically remote from the student or which has no immediate normal reality" (Hatherly, n. d.; Al Musawi, Ambusaidi, Al-Balushi \& Al-Balushi, 2015). It can be described as a tool consists of interactive computerized software linked with sensitive connector endings called sensors, where the components of practical sciences experiments are integrated with computers as a measurement instrument to collect and analyze data (Al-Shaiey, 2006; Al Musawi et al. 2015).

3DL is used with the aim to improve the normal lab work and keep pace with the technological developments, utilizing computer-programming abilities to construct educational experiences and practices. Science teachers can fill in for the traditional lab equipment/tools' defects by using 3D software where it helps learners to profoundly comprehend science ideas and resolve their preconceived scientific misunderstandings. 3DL can be used aiming to form and improve learners' positive attitudes towards science and technology (Shaheen \& Khattab, 2005, p. 206; Al Musawi et al. 2015).

\subsubsection{Components and Types of 3DL}

Al-Bayati (2006) specifies that 3DL comprises of main components such as laboratory tools including various old-style laboratories with few improvements to help in their application inside the lab and 3DLs. The latter are provided with computers, laptops, or tablets linked to the school servers and Internet to enable the students to work in the lab or distantly whenever or wherever they want to get to the system. The computers and servers must have the lab software and simulation programs that permit their interaction with the virtual experiments. The communication system operates when all the clients are working remotely with the 3DL to conduct an experiment, the whole system interface ought to be associated with their computers and servers and the communication channels should be profoundly secured and reliable as required by the experiment. It is important to supply these labs with reasonable cost keeping in mind the end goal to set up communication between the clients and the 3DL in which they can carry out all the required experiments 3DL software (pp. 28-32).

There are two types of 3DL software. One teaches the client to figure out how to conduct experiment giving them the required data. The other controls the lab by integrating special $3 \mathrm{DL}$, simulation programs and preliminary training of the clients on the most proficient method to implement the system effectively. The participation and management software includes how to administer the lab and the clients' involvement. This software enlists the clients and decides access types they can get to work in different experiments. The significance of such software lies in their capacity to enable each participant group to conduct the experiment as indicated by specific levels, for example, enabling them to work at a specific stage on few investigations and tools that suit them (Al-Shahri, 2009, p. 72; Al Musawi et al. 2015).

Based on the above, there are different types of 3DL. The first are the 'computerized science labs'. These are two-dimensional labs depend on sensors for testing and performing analyses. They incorporate the design of various lab's experiments that are accessible to the client on the computer or saved on DVDs and CDs. This type does not provide the learner with the required level of engagement into the virtual environment. The second type are 'online simulation labs', which are normal two-dimensional labs that include experiments and offer various investigations and analyses in short video formats. This system is accessible on the Internet so anybody can see and control them. Notwithstanding, the level of the students' involvement with the experiment and their capacity to transform them is restricted. The third type are 'electronic labs' that provide practical experiences and analyses closer to certainty. The system is introduced in two-or-three dimensional formats associated with by sound, image and movement. Their electronic environments are adjustable and manageable. They offer a great deal of interaction between the clients and 2D or 3D settings and allow more than one client to explore the lab and communicate with others. The fourth type is '3DLs', which are virtual reality software of true experiments. They are similar to the electronic labs described in type three above yet they utilize new advanced gadgets such as goggles, head-mounted displays, gloves, and tracking system and enable the client to participate in an enriched virtual reality environment with physical interaction of the eyes, ears and hands. Efforts keep on involving all parts of the client's body through a full body dress that links senses and brain zones with feedback controllers to achieve immediate contact with the skin surface of the client bringing about an entire human contact with virtual reality exploration (Zaitun, 2002, p. 165; Farooq et al, 2013; Al Musawi et al. 2015). 


\subsubsection{Pros and Cons of 3DL Use}

$3 \mathrm{DL}$ is a progressive technologic method in the field of science education through which the learner uses computers not just as an instrument for data keeping or processing but also as a lab for estimation and control. Additionally, it turns into an instrument to reflect and decide on experiments in connection to hypotheses so the students can comprehend their importance. They can utilize the 3DL as a way to find the laws through actual measurements while doing these experiments. They can see how chemical compounds are made and how they work (Al-Balushi \& Al-Hajri, 2014). In this way, 3DL fills in as a device to recognize and persuade through review, experimentation and conclusion (Al Musawi et al. 2015).

Zaitun (2002) reports that 3DL can be an excellent replacement for conventional lab as it offers learners with experiences similar to direct ones while resolving impediments that may hinder conducting real experiments. It also allows students to interact with attractive and dynamic scientific situations and manage their practical analysis with instantaneous feedback (p.164). In addition, 3DL advances educational program by furnishing learners with experiences that would be excessively unsafe or restrictively costly in a traditional setup. It can utilize interesting visual representations that support deep understanding of phenomena not directly observable or accessible in traditional labs (Coble et al. 2010; Al Musawi et al. 2015).

The virtual labs are generally limited by the need to operate by computers and hardware with efficient technical specifications for clear depiction of multifaceted phenomena. In addition, specialists from different branches of science such as programming, curriculum and psychology must be employed to design and produce them. 3DLs production should be contextualized culturally in terms of students' language and content, a case applied to the Omani setting where the medium of instruction is Arabic (Al Musawi et al. 2015).

\subsubsection{Previous Studies in the Arab World}

Experimental research conducted in the Arab World on electronic and virtual labs and resulted in a better students' academic achievement of scientific concepts in favor of the group that studied using these labs (Al-Mutairi, 1998; Al-Anzi, 2003; Al-Shannaq et al., 2004; Shabbat, 2005; Al-Shaiey, 2006; Al-Radi, 2008). In addition, the achievement means in levels of memorization, understanding, and application were all in favor of the experimental group (Al-Qarni, 2006). In Al-Shaiey study (2006), the results showed that the majority of the teacher sample (62 percent) used the electronic labs once at least during the semester. The study also showed positive attitudes between these teachers and their students towards using the electronic laboratories (Al Musawi et al. 2015).

Saleh, Al-Hadi \& Al-Qadhi (2004) indicated the effectiveness of virtual lab especially when utilized alone to accomplish the lessons' objectives in terms of acquiring laboratory skills. Al-Khalaf study (2005) attributed to the impact of interaction between teaching method and gender in the achievement and skills tests to the use of virtual lab. Both Redha (2010) and Ahmad (2010) pointed out the effectiveness of the virtual lab investigating and demonstrating part in developing scientific thinking in addition to increasing the achievement in academic concepts. In Oman, Al-Balushi (2009) study revealed better post-test academic achievement and practical skills in favor of the group that studied using the virtual lab. The post-test also demonstrate positive attitudes towards this lab among the Omani students.

In light of the above reviewed research, this paper focuses on methods and procedures used to plan this investigation as part of a national project funded by The Research Council and aims to measure the effectiveness of the 3DL on Omani students' acquisition of practical abilities and skills (Al Musawi et al. 2015).

\subsection{Study Questions}

1. What effect does the 3DL have on Omani fourth graders' achievement?

2. What are the attitudes of Omani fourth graders towards the use of 3DL in science education?

3. What effect does the 3DL have on developing and acquiring logical and visual thinking by the Omani fourth graders?

\section{Method}

This study followed a quantitative method, particularly experimental research, to measure the effectiveness of the 3DL towards the following cognitive variables:

- academic achievement

- $\quad$ science processes

- $\quad$ scientific attitudes

- estimation of classroom environment 
- practical skills

- visual thinking

- $\quad$ attitudes towards 3DL.

\subsection{Research Design}

The study investigates the effectiveness of the use of 3DL in science education, the acquisition of practical skills, and basic education learners' attitudes towards classroom environment and using 3DL lab in their learning. The following subsections include description of the participants or subjects and a section describing the procedures used in the study. In addition to the research design.

\subsection{Participants}

This study applied experimental design, namely, "Pre-Post Test Control Group Design". In this design, each of the experimental and control groups consisted of 30 students who went through academic achievement tests.

\subsection{Research Tools}

To achieve the study objectives, the following tools and scales were used:

1. Academic Achievement test: subject teachers prepared this test according to the lessons' plans. Its questions covers most of the scientific topics learned by both groups' students. The total score is used to calculate learners' science ability. The test is completed and corrected, and the teachers recorded scores for both groups' students.

2. Logical thinking scale: a standardized scale from Al-Hadhrami \& Ambusaidi (2012). It was used to measure the logical thinking of Omani twelfth graders, similar grade level to this study's sample, with 0.72 reliability coefficient.

3. Visual thinking scale: a standardized scale from Al-Balushi \& Al-Hajri (2014) to investigate the effectiveness of the 3DL in developing visual thinking.

4. Attitudinal scale: this is a standardized scale towards 3DL adopted from Al Balushi (2009) study. It includes negative and positive statements, with three answers' options: agree, neutral, and disagree. Positive statements are scored as $(1,2,3)$; whereas negative statements are scored reversely $(3,2,1)$.

\subsubsection{The 3D lab}

The 3DL used is called Eureka ${ }^{\circledR}$ which consists of collection of 3D animated and interactive instructional Arabic/English units in biology, physics and chemistry. The unit's materials adapted to the Omani science curriculum and suitable for the fourth basic education class were selected. The students watched the lessons during their learning used goggles. In addition, students used thirty tablets (Samsung® Galaxy Note) for the activities and interactions with the lessons.

\subsubsection{Experimental Interventions}

This study applied experimental design, namely, "Pre-Post Test Control Group Design". The experimental group was exposed to experimental treatment by learning through the 3DL. The teachers participated in the experiment after training to use the virtual lab and selection of science lessons. The experimental group's students used tablets to plug in to the 3D lab software and Internet while carrying out the experiments during the lessons under teacher supervision. Then, both the experimental and control groups took achievement and practical tests. Table (1) is a summary of the experimental interventions. It shows the Pretest and Posttest treatments given for both experimental and control groups along with the experimental treatment given to the experimental group. The control group used the traditional teaching methods.

Table 1. Experimental Interventions

\begin{tabular}{|c|c|c|c|}
\hline Group & Pretests & $\begin{array}{l}\text { Experimental } \\
\text { Treatment }\end{array}$ & Posttests \\
\hline $\begin{array}{l}\text { Experiment } \\
\text { al }\end{array}$ & $\begin{array}{l}\text { achievement test } \\
\text { logical thinking } \\
\text { attitudinal scale towards 3D-lab } \\
\text { visual thinking scale }\end{array}$ & $\begin{array}{l}\text { use 3D-lab in } \\
\text { teaching }\end{array}$ & $\begin{array}{l}\text { achievement test } \\
\text { logical thinking } \\
\text { attitudinal scale towards 3D-lab } \\
\text { visual thinking scale }\end{array}$ \\
\hline Control & $\begin{array}{l}\text { achievement test } \\
\text { logical thinking } \\
\text { attitudinal scale towards 3D-lab } \\
\text { visual thinking scale }\end{array}$ & $\begin{array}{lr}\text { use } & \text { traditional } \\
\text { methods } & \text { in } \\
\text { teaching } & \text { (no } \\
\text { 3D-lab) } & \end{array}$ & $\begin{array}{l}\text { achievement test } \\
\text { logical thinking } \\
\text { attitudinal scale towards w3D-lab } \\
\text { visual thinking scale }\end{array}$ \\
\hline
\end{tabular}




\section{Results}

\subsection{Achievement}

To answer the research question: "What effect does the 3DL have on Omani fourth graders' achievement?"; improvement of experimental and control groups' achievement average scores in pre and posttests is calculated using t-test of the (Paired-Samples-t- Test); as shown in the Table (2).

Table 2. Means, standard deviations, and ( $\mathrm{t}$ ) value of experimental and control groups' achievement average scores in pre and posttests

\begin{tabular}{|c|c|c|c|c|c|c|c|}
\hline Test levels & Group & $\begin{array}{l}\text { Test } \\
\text { type }\end{array}$ & Means & $\begin{array}{l}\text { Standard } \\
\text { Deviations }\end{array}$ & df & $\mathbf{t}$ & Sig \\
\hline \multirow[t]{4}{*}{ Knowledge } & \multirow{4}{*}{$\begin{array}{l}\text { Experime } \\
\text { ntal } \\
\text { Control }\end{array}$} & Pre & 3.31 & 1.53 & \multirow[t]{2}{*}{26} & \multirow[t]{2}{*}{6.24} & \multirow[t]{2}{*}{$0.001 *$} \\
\hline & & Post & 5.11 & 1.98 & & & \\
\hline & & Pre & 3.83 & 1.39 & \multirow[t]{2}{*}{26} & \multirow[t]{2}{*}{5.88} & \multirow[t]{2}{*}{$0.001 *$} \\
\hline & & Post & 5.61 & 2.31 & & & \\
\hline \multirow[t]{4}{*}{ Application } & \multirow{4}{*}{$\begin{array}{l}\text { Experime } \\
\text { ntal } \\
\text { Control }\end{array}$} & Pre & 6.11 & 3.99 & \multirow[t]{2}{*}{26} & \multirow[t]{2}{*}{0.30} & \multirow[t]{2}{*}{0.771} \\
\hline & & Post & 6.26 & 3.13 & & & \\
\hline & & Pre & 4.76 & 3.49 & \multirow[t]{2}{*}{26} & \multirow[t]{2}{*}{2.66} & \multirow[t]{2}{*}{$0.031 *$} \\
\hline & & Post & 6.07 & 3.93 & & & \\
\hline \multirow{4}{*}{$\begin{array}{l}\text { Metacogniti } \\
\text { ve abilities }\end{array}$} & \multirow{4}{*}{$\begin{array}{l}\text { Experime } \\
\text { ntal } \\
\text { Control }\end{array}$} & Pre & 3.11 & 1.79 & \multirow[t]{2}{*}{26} & \multirow[t]{2}{*}{5.40} & \multirow[t]{2}{*}{0.001 * } \\
\hline & & Post & 4.65 & 1.85 & & & \\
\hline & & Pre & 2.24 & 1.50 & \multirow[t]{2}{*}{26} & \multirow[t]{2}{*}{6.71} & \multirow[t]{2}{*}{ 0.001* } \\
\hline & & Post & 4.17 & 2.32 & & & \\
\hline \multirow[t]{4}{*}{ Overall sum } & \multirow{4}{*}{$\begin{array}{l}\text { Experime } \\
\text { ntal } \\
\text { Control }\end{array}$} & Pre & 12.54 & 6.76 & \multirow[t]{2}{*}{26} & \multirow[t]{2}{*}{4.96} & \multirow{4}{*}{$0.001 *$} \\
\hline & & Post & 16.02 & 6.01 & & & \\
\hline & & Pre & 11.02 & 5.41 & \multirow[t]{2}{*}{26} & \multirow[t]{2}{*}{5.75} & \\
\hline & & Post & 15.85 & 8.10 & & & \\
\hline
\end{tabular}

*Significance at $(\alpha \leq 0.05)$

Table (2) shows that there is improvement in the achievement test of both experimental and control groups, but the degree of improvement levels of the experimental group's students may be better than the control group's students as a result of their teaching with 3DL. Statistically significant differences can be observed in favor of the post application for the experimental group in the achievement test as a whole as well as for the two levels of knowledge and metacognitive abilities. No statistically significant difference is found for the application level.

To identify the effect size of using 3DL on achievement improvement of the experimental group's students, $\eta 2$ using the equation $\eta 2=t 2 /(t 2+d f)$, was calculated; where $(t)$ is the value of $(t)$ of the overall sum, and $(\mathrm{df})$ is the degrees of freedom; as shown in Table (3).

Table 3. ( $\eta 2$ ) value and the effect size of using 3DL on the achievement improvement of the experimental group

\begin{tabular}{llll}
\hline Independent variable & Dependent variable & $\boldsymbol{\eta}^{2}$ & Effect size \\
Using 3DL & Achievement improvement & $\mathbf{0 . 4 8 6}$ & large \\
\hline
\end{tabular}

Table (3) shows that the effect size of using 3DL for the study sample is large. (49\%) of the total variation of the dependent variable (achievement test improvement levels) is due to the effect of the independent variable (using the 3DL). This percentage is higher than the one set by Cohen (15\% or more), in order to consider the effect size of the independent variable on the dependent variable as large.

\subsection{Attitudes}

To answer the research question: "What are the attitudes of Omani fourth graders towards the use of 3DL in science education?" frequencies and percentages of the experimental group responses according to their attitudes towards 3DL were calculated as shown in the Table (4). 
Table 4. Frequencies and percentages of the experimental group responses according to their attitudes towards 3DL*

\begin{tabular}{|c|c|c|c|c|c|c|}
\hline \multirow[t]{2}{*}{ Items } & \multicolumn{2}{|l|}{ Agree } & \multicolumn{2}{|c|}{ Not Sure } & \multicolumn{2}{|c|}{ Disagree } \\
\hline & Freq. & $\%$ & Freq. & $\%$ & Freq. & $\%$ \\
\hline Work in the 3DL worrying and tiresome. & - & - & - & - & 26 & $100 \%$ \\
\hline Learning science through $3 \mathrm{DL}$ is exciting and interesting & 25 & $96.2 \%$ & - & - & - & - \\
\hline $\begin{array}{l}\text { 3DL focuses on learning through observation, deduction, inquiry, and } \\
\text { exploration thus enhancing my scientific knowledge. }\end{array}$ & 22 & $84.6 \%$ & 2 & $7.7 \%$ & 2 & $7.7 \%$ \\
\hline $\begin{array}{l}\text { I like the conducting practical experiments and procedural activities through } \\
\text { 3DL. }\end{array}$ & 26 & $100 \%$ & - & - & - & - \\
\hline 3DL helps me to form accurate mental images about the learning subject. & 23 & $88.5 \%$ & 3 & $11.5 \%$ & - & - \\
\hline I like the idea of having an integrated 3DL using the computer tablet. & 24 & $92.3 \%$ & - & - & 2 & $7.7 \%$ \\
\hline $\begin{array}{l}\text { I like the } 3 \mathrm{DL} \text { form and design that include the contents of interesting scientific } \\
\text { materials and tools. }\end{array}$ & 24 & $92.3 \%$ & 1 & $3.8 \%$ & 1 & $3.8 \%$ \\
\hline $\begin{array}{l}\text { I like the diversity, design accuracy, and ease of use of scientific lessons, } \\
\text { activities and instruments in the 3DL library. }\end{array}$ & 25 & $92.2 \%$ & - & - & 1 & $3.8 \%$ \\
\hline I do not feel the time goes when conducting practical experiments in the 3DL. & 17 & $65.4 \%$ & 5 & $19.2 \%$ & 4 & $15.4 \%$ \\
\hline $\begin{array}{l}\text { I can make practical experiments and record my observations and results in a } \\
\text { calm atmosphere. }\end{array}$ & 21 & $80.8 \%$ & 1 & $3.8 \%$ & 4 & $15.4 \%$ \\
\hline I do not like making practical experience using 3DL & 6 & $23.1 \%$ & - & - & 19 & $73.1 \%$ \\
\hline $\begin{array}{l}\text { I see that the 3DL provide me with new skills and develop my practical } \\
\text { performance in laboratory experiments. }\end{array}$ & 24 & $92.3 \%$ & 1 & $3.8 \%$ & 1 & $3.8 \%$ \\
\hline I feel confident when conducting practical experiments using the 3DL. & 22 & $84.6 \%$ & 2 & $7.7 \%$ & 2 & $7.7 \%$ \\
\hline $\begin{array}{l}\text { I feel that I am interactive learner while using the 3DL rather than being a } \\
\text { recipient of the information only. }\end{array}$ & 24 & $92.3 \%$ & 1 & $3.8 \%$ & 1 & $3.8 \%$ \\
\hline 3DL tools help me to assess my laboratory skills independently. & 25 & $96.2 \%$ & 1 & $3.8 \%$ & - & - \\
\hline I like the idea of self-learning through 3DL. & 23 & $88.5 \%$ & - & - & 3 & $11.5 \%$ \\
\hline $\begin{array}{l}\text { I feel happy and enthusiastic when conducting practical experiments through } \\
\text { 3DL more than I do with the traditional lab. }\end{array}$ & 23 & $88.5 \%$ & 2 & $7.7 \%$ & 1 & $3.8 \%$ \\
\hline $\begin{array}{l}\text { I can continue making practical experiments and taking notes at my pace of } \\
\text { learning. }\end{array}$ & 20 & $76.9 \%$ & 3 & $115 \%$ & 3 & $11.5 \%$ \\
\hline I do not need the presence of a technician when using 3DL to do experiments. & 15 & $57.7 \%$ & 2 & $7.7 \%$ & 9 & $34.6 \%$ \\
\hline 3DL made me love science despite difficulties. & 26 & $100 \%$ & - & - & - & - \\
\hline I feel free and enjoy repeating experiments until I master learning. & 24 & $92.3 \%$ & - & - & 2 & $7.7 \%$ \\
\hline Learning scientific shapes, symbols and equations becomes easy with 3DL. & 24 & $92.3 \%$ & 2 & $7.7 \%$ & - & - \\
\hline I fear not to make mistakes when conducting experiments in the 3DL. & 18 & $69.2 \%$ & 2 & $7.7 \%$ & 5 & $19.2 \%$ \\
\hline $\begin{array}{l}\text { 3DL makes me feel safe and secure when dealing with laboratory materials and } \\
\text { hazardous experiments. }\end{array}$ & 23 & $88.5 \%$ & 1 & $3.8 \%$ & 2 & $7.7 \%$ \\
\hline $\begin{array}{l}\text { There is difficulty in transferring the results and observations of my colleagues } \\
\text { in the 3DL. }\end{array}$ & 8 & $32.0 \%$ & 2 & $8.0 \%$ & 15 & $60.0 \%$ \\
\hline I trust my ability to conduct practical experiments by myself without a guide. & 21 & $96.3 \%$ & - & - & 5 & $19.2 \%$ \\
\hline I feel I can work well using the 3DL. & 26 & $100 \%$ & - & - & - & - \\
\hline $\begin{array}{l}\text { I am confident that the materials and tools that I need for experiments are } \\
\text { available in the } 3 \mathrm{DL} \text {. }\end{array}$ & 25 & $96.2 \%$ & - & - & 1 & $3.8 \%$ \\
\hline 3DL allows individual and group work. & 23 & $88.5 \%$ & 2 & $7.7 \%$ & 1 & $3.8 \%$ \\
\hline What I learn through 3DL integrates with what I learn in theory sessions. & 19 & $73.1 \%$ & 2 & $7.7 \%$ & 5 & $19.2 \%$ \\
\hline There are clear instructions to guide my activities in the 3DL. & 23 & $92.0 \%$ & 1 & $4.0 \%$ & 1 & $4.0 \%$ \\
\hline I worry and fear when dealing with 3DL. & 3 & $11.5 \%$ & 1 & $3.8 \%$ & 22 & $84.6 \%$ \\
\hline I like to be an 3DL educational designer in the future. & 24 & $92.3 \%$ & 1 & $3.8 \%$ & 1 & $3.8 \%$ \\
\hline $\begin{array}{l}\text { I feel bad for the length of time when conducting practical experiments and } \\
\text { learning through } 3 \mathrm{DL} \text {. }\end{array}$ & 8 & $30.8 \%$ & - & - & 18 & $69.2 \%$ \\
\hline I can mail from the laboratory to make any practical experiment without fear. & 22 & $84.6 \%$ & 3 & $11.5 \%$ & 1 & $3.8 \%$ \\
\hline $\begin{array}{l}\text { 3DL helps me to organize thinking and expect results more than the traditional } \\
\text { lab does. }\end{array}$ & 24 & $92.3 \%$ & 1 & $3.8 \%$ & 1 & $3.8 \%$ \\
\hline 3DL does not help the development of laboratory skills types. & 9 & $34.6 \%$ & - & - & 17 & $65.4 \%$ \\
\hline $\begin{array}{l}\text { It worries me to think that the information may be erased because of pressing } \\
\text { the wrong button in the } 3 \mathrm{DL} \text {. }\end{array}$ & 6 & $23.1 \%$ & 3 & $11.5 \%$ & 17 & $65.4 \%$ \\
\hline $\begin{array}{l}\text { I love to write practical experiment report and equations using } 3 \mathrm{DL} \text { rather than } \\
\text { doing that in the traditional lab. }\end{array}$ & 24 & $92.3 \%$ & - & - & 2 & $7.7 \%$ \\
\hline I like the hands-on training of basic skills required to use the laboratory tools & 24 & $92.3 \%$ & 1 & $3.8 \%$ & 1 & $3.8 \%$ \\
\hline
\end{tabular}

\footnotetext{
* Adapted from Al Balushi (2009).
} 
It is evident from Table (IV) that there is an agreement among the members of the sample regarding the importance of 3DL with positive attitude towards it. Further, means, standard deviations, and level of statistical significance of the average scores of the experimental and control groups posttest in the attitudinal scale towards 3DL are calculated. Table (5) shows the findings.

Table 5. Means, standard deviations, and (t) of the mean scores of the experimental and control groups posttest in the attitudinal scale towards 3DL

\begin{tabular}{lllllll}
\hline Group & Items & Means & SD & df & t & Sig. \\
$\begin{array}{l}\text { Experimental } \\
\text { Control }\end{array}$ & 40 & 2.56 & 0.150 & 52 & 4.97 & $0.001^{*}$ \\
\hline
\end{tabular}

* Significance at $(\alpha \leq 0.05)$

Table (5) shows significant differences between the mean scores of the experimental and control groups posttest in the attitudinal scale towards 3DL in favor of the experimental group. This finding emphasizes the positive attitude of the sample towards the 3DL.

\subsection{Logical Thinking}

To answer the research question: "What effect does the 3DL have on developing and acquiring logical thinking by the Omani fourth graders?" the logical thinking test is applied at the end of the experiment. Then, the means, standard deviations, and Multivariate analysis of variance (MANOVA) test are conducted to calculate the statistical significance of differences between both study groups; as shown in the Table (6).

Table 6. Means, standard deviations, and (F) of the mean scores of the experimental and control groups posttest in the logical thinking test.

\begin{tabular}{lllllll}
\hline Logical thinking skills & Group & Means & SD & df & F & \\
& & & & & & Sig. \\
Proportional reasoning & Experimental & 0.81 & 1.04 & 52 & 0.519 & $\mathbf{0 . 4 7 4}$ \\
& Control & 0.63 & 0.84 & & & \\
Controlling variables & Experimental & 0.89 & 0.97 & 52 & 4.376 & $\mathbf{0 . 0 4 1 *}$ \\
& Control & 0.41 & 0.69 & & & \\
Probabilistic inference & Experimental & 1.33 & 1.07 & 52 & 0.082 & $\mathbf{0 . 7 7 6}$ \\
& Control & 1.26 & 0.81 & & & \\
Correlational inference & Experimental & 2.11 & 0.64 & 52 & 0.047 & $\mathbf{0 . 8 2 9}$ \\
& Control & 2.07 & 0.62 & & & \\
Total & Experimental & 5.19 & 1.33 & 52 & 3.487 & $\mathbf{0 . 0 6 7}$ \\
& Control & $\mathbf{4 . 3 3}$ & $\mathbf{1 . 9 6}$ & & & \\
\hline
\end{tabular}

* Significance at $(\alpha \leq 0.05)$ - each skill scores $=4$, Total test scores $=16$.

Table (6) shows no significant differences between the mean scores of experimental and control groups on the overall logical thinking skills posttest. However, it shows significant differences between the mean scores of experimental and control groups in one logical thinking skill only: controlling variables skill.

The improvement of logical thinking skills for both study groups in pre and posttest is calculated using Paired-Samples-t- Test. Findings are listed in Table (7). 
Table 7. Means, standard deviations, and ( $\mathrm{t}$ ) of the mean scores of the experimental and control groups pre and posttest in the logical thinking test

\begin{tabular}{|c|c|c|c|c|c|c|c|}
\hline \multicolumn{2}{|l|}{ Logical thinking skills } & Test type & Means & SD & df & $\mathbf{t}$ & Sig. \\
\hline \multirow[t]{4}{*}{ Proportional reasoning } & Experimental & Pre & 0.67 & 0.88 & 26 & 0.57 & 0.574 \\
\hline & & Post & 0.81 & 1.04 & & & \\
\hline & & Pre & 0.52 & 0.85 & 26 & 0.52 & 0.611 \\
\hline & Control & Post & 0.63 & 0.84 & & & \\
\hline \multirow[t]{4}{*}{ Controlling variables } & Experimental & Pre & 0.48 & 0.80 & 26 & 2.51 & 0.019* \\
\hline & & Post & 0.89 & 0.97 & & & \\
\hline & & Pre & 0.48 & 0.70 & 26 & 0.40 & 0.611 \\
\hline & Control & Post & 0.41 & 0.69 & & & \\
\hline \multirow[t]{5}{*}{ Probabilistic inference } & Experimental & Pre & 1.15 & 0.99 & 26 & 1.00 & 0.327 \\
\hline & & Post & 1.33 & 1.07 & & & \\
\hline & & Pre & 1.15 & 0.95 & 26 & 0.44 & 0.663 \\
\hline & Control & Post & 1.26 & 0.81 & & & \\
\hline & Experimental & Pre & 1.67 & 0.88 & 26 & 2.06 & $0.050 *$ \\
\hline \multirow[t]{3}{*}{ Correlational inference } & & Post & 2.11 & 0.64 & & & \\
\hline & & Pre & 1.78 & 0.80 & 26 & 1.44 & \\
\hline & Control & Post & 2.07 & 0.62 & & & 0.161 \\
\hline \multirow[t]{4}{*}{ Total } & Experimental & Pre & 3.96 & 1.81 & 26 & 4.64 & $0.001 *$ \\
\hline & & Post & 5.19 & 1.96 & & & \\
\hline & & Pre & 3.93 & 1.41 & 26 & 1.52 & 0.141 \\
\hline & Control & Post & 4.33 & 1.33 & & & \\
\hline
\end{tabular}

* Significance at $(\alpha \leq 0.05)$

Table (7) shows that there is an improvement in logical thinking skills for both experimental and control groups, but the degree of improvement of the experimental group students increases better than the control group students as a result of their learning using the 3DL. Statistical significant differences exist in the overall posttest and in controlling variables and correlational inference skills in favor of the experimental group. There were no statistically significant differences for proportional reasoning and probabilistic reasoning skills pre and posttest for both the experimental and the control groups.

Table (8) shows calculations used to identify the effect size of using 3DL on logical thinking skills acquisition improvement of the experimental group's students, $\eta 2$ using the equation $\eta 2=\mathrm{t} 2 /(\mathrm{t} 2+\mathrm{df})$, was calculated; where (t) is the value of (t) of the overall sum, and (df) is the degrees of freedom; as shown in Table (8).

Table 8. ( $\eta 2$ ) value and the effect size of using 3DL on the logical thinking skills acquisition of the experimental group

\begin{tabular}{lllll}
\hline Independent variable & $\begin{array}{l}\text { Dependent variable } \\
\text { Using 3DL }\end{array}$ & \multicolumn{1}{c}{$\boldsymbol{\eta}^{2}$} & Effect size \\
Logical thinking & skills & $\mathbf{0 . 4 5 3}$ & large \\
& acquisition improvement
\end{tabular}

Table (8) shows that the effect size of using 3DL for the study sample is large. (45\%) of the total variation of the dependent variable (logical thinking skills acquisition improvement levels) is due to the effect of the independent variable (using the 3DL). This percentage is higher than the one set by Cohen (15 percent or more), in order to consider the effect size of the independent variable on the dependent variable as large.

The growth rate of the logical thinking skills for both experimental and control groups in the pre and posttests is calculated as shown in the Table (9).

Table 9. Growth rates of the logical thinking skills of for both experimental and control groups in the pre and posttests

\begin{tabular}{llllllll}
\hline $\begin{array}{l}\text { Logical } \\
\text { thinking skills }\end{array}$ & Total & \multicolumn{2}{l}{ Experimental Group } & Growth & \multicolumn{2}{l}{ Control Group } & Growth \\
Score & M1 & Posttest & Rate & Pretest & Posttest & Rate \\
$\begin{array}{l}\text { Proportional } \\
\text { reasoning }\end{array}$ & 4 & 0.67 & 0.81 & $3.50 \%$ & 0.52 & 0.63 & $\mathbf{2 . 7 5 \%}$ \\
$\begin{array}{l}\text { Controlling } \\
\text { variables }\end{array}$ & 4 & 0.48 & 0.89 & $10.25 \%$ & 0.48 & 0.41 & $\mathbf{1 . 7 5 - \%}$ \\
$\begin{array}{l}\text { Probabilistic } \\
\text { inference }\end{array}$ & 4 & 1.15 & 1.33 & $4.50 \%$ & 1.15 & 1.26 & $\mathbf{2 . 7 5 \%}$ \\
$\begin{array}{l}\text { Correlational } \\
\text { inference }\end{array}$ & 4 & 1.67 & 2.11 & $11 \%$ & 1.78 & 2.07 & $\mathbf{7 . 2 5 \%}$ \\
Total & $\mathbf{1 6}$ & $\mathbf{3 . 9 6}$ & $\mathbf{5 . 1 9}$ & $\mathbf{7 . 6 9 \%}$ & $\mathbf{3 . 9 3}$ & $\mathbf{4 . 3 3}$ & $\mathbf{2 . 5 0 \%}$ \\
\hline
\end{tabular}


Table (9) shows differences between the growth rates in the means of the experimental and control groups, where the logical thinking skills growth rate of the experimental group is higher than the growth rate of the control group. In addition, controlling variables and correlational inference skills are higher in their growth rates compared to the other two skills. It is also noted the lack of growth of control variables skill of the control group.

To identify the extent to which the experimental group students respond to the logical thinking items and the ways in which they used to solve the questions, frequencies and percentages of their responses to this test are calculated as shown in the Table (10).

Table 10. Frequencies and percentages of the experimental group students to the logical thinking posttest items

\begin{tabular}{|c|c|c|c|c|c|c|c|c|}
\hline Question & & & & & Reason & & & \\
\hline $\begin{array}{l}\text { Question } \\
\text { No. }\end{array}$ & Options & $\begin{array}{l}\text { The } \\
\text { Correct } \\
\text { Answer }\end{array}$ & Frequencies & Percentages & Options & $\begin{array}{l}\text { The } \\
\text { correct } \\
\text { answer }\end{array}$ & Frequencies & Percentages \\
\hline First & $\mathrm{a}$ & $\mathrm{c}$ & 8 & $33.3 \%$ & 1 & 3 & 3 & $12.5 \%$ \\
\hline & $\mathrm{b}$ & & 8 & $33.3 \%$ & 2 & & 13 & $54.2 \%$ \\
\hline & $\mathrm{c}$ & & 4 & $16.7 \%$ & 3 & & 3 & $12.5 \%$ \\
\hline & $\mathrm{d}$ & & 3 & $12.5 \%$ & 4 & & 1 & $4.2 \%$ \\
\hline & $\mathrm{e}$ & & 1 & $4.2 \%$ & 5 & & 4 & $16.7 \%$ \\
\hline Second & $\mathrm{a}$ & $\mathrm{c}$ & 0 & $0 \%$ & 1 & 5 & 4 & $16.7 \%$ \\
\hline & $\mathrm{b}$ & & 8 & $33.3 \%$ & 2 & & 4 & $16.7 \%$ \\
\hline & $\mathrm{c}$ & & 7 & $29.2 \%$ & 3 & & 4 & $16.7 \%$ \\
\hline & $\mathrm{d}$ & & 7 & $29.2 \%$ & 4 & & 10 & $41.7 \%$ \\
\hline & $\mathrm{e}$ & & 2 & $8.3 \%$ & 5 & & 2 & $8.3 \%$ \\
\hline Third & $\mathrm{a}$ & $\mathrm{c}$ & 0 & $0 \%$ & 1 & 4 & 1 & $4.3 \%$ \\
\hline & $\mathrm{b}$ & & 7 & $29.2 \%$ & 2 & & 12 & $52.2 \%$ \\
\hline & $\mathrm{c}$ & & 6 & $25.0 \%$ & 3 & & 5 & $21.7 \%$ \\
\hline & d & & 5 & $20.8 \%$ & 4 & & 4 & $17.4 \%$ \\
\hline & $\mathrm{e}$ & & 6 & $25.0 \%$ & 5 & & 1 & $4.3 \%$ \\
\hline Fourth & $\mathrm{a}$ & $\mathrm{a}$ & 6 & $25.0 \%$ & 1 & 4 & 12 & $52.2 \%$ \\
\hline & $\mathrm{b}$ & & 6 & $25.0 \%$ & 2 & & 4 & $17.4 \%$ \\
\hline & $\mathrm{c}$ & & 3 & $12.5 \%$ & 3 & & 3 & $13.0 \%$ \\
\hline & $\mathrm{d}$ & & 6 & $25.0 \%$ & 4 & & 4 & $17.4 \%$ \\
\hline & $\mathrm{e}$ & & 3 & $12.5 \%$ & 5 & & 0 & $0 \%$ \\
\hline Fifth & $\mathrm{a}$ & $\mathrm{a}$ & 12 & $50.0 \%$ & 1 & & 12 & $50.0 \%$ \\
\hline & $\mathrm{b}$ & & 3 & $12.5 \%$ & 2 & & 4 & $16.7 \%$ \\
\hline & $\mathrm{c}$ & & 5 & $20.8 \%$ & 3 & 1 & 2 & $8.3 \%$ \\
\hline & $\mathrm{d}$ & & 3 & $12.5 \%$ & 4 & & 4 & $16.7 \%$ \\
\hline & $\mathrm{e}$ & & 1 & $4.2 \%$ & 5 & & 2 & $8.3 \%$ \\
\hline Sixth & $\mathrm{a}$ & $\mathrm{b}$ & 3 & $12.5 \%$ & 1 & 2 & 10 & $43.5 \%$ \\
\hline & $\mathrm{b}$ & & 6 & $25.0 \%$ & 2 & & 4 & $17.4 \%$ \\
\hline & $\mathrm{c}$ & & 4 & $16.7 \%$ & 3 & & 5 & $21.7 \%$ \\
\hline & $\mathrm{d}$ & & 3 & $12.5 \%$ & 4 & & 3 & $13.0 \%$ \\
\hline & $\mathrm{e}$ & & 8 & $33.3 \%$ & 5 & & 1 & $4.3 \%$ \\
\hline Seventh & $\mathrm{a}$ & $\mathrm{a}$ & 24 & $100 \%$ & 1 & 4 & 2 & $8.3 \%$ \\
\hline & $\mathrm{b}$ & & 0 & $0 \%$ & 2 & & 15 & $62.5 \%$ \\
\hline & $\mathrm{c}$ & & 0 & $0 \%$ & 3 & & 3 & $12.5 \%$ \\
\hline & $\mathrm{d}$ & & 0 & $0 \%$ & 4 & & 2 & $8.3 \%$ \\
\hline & $\mathrm{e}$ & & 0 & $0 \%$ & 5 & & 2 & $8.3 \%$ \\
\hline Eighth & $\mathrm{a}$ & $\mathrm{b}$ & 5 & $20.8 \%$ & 1 & 5 & 3 & $12.5 \%$ \\
\hline & $\mathrm{b}$ & & 19 & $79.2 \%$ & 2 & & 12 & $50.0 \%$ \\
\hline & $\mathrm{c}$ & & 0 & $0 \%$ & 3 & & 5 & $20.8 \%$ \\
\hline & $\mathrm{d}$ & & 0 & $0 \%$ & 4 & & 1 & $4.2 \%$ \\
\hline & $\mathrm{e}$ & & 0 & $0 \%$ & 5 & & 3 & $12.5 \%$ \\
\hline
\end{tabular}

Table (10) shows that the percentage of those who have the correct answer for the first and second questions is weak. The highest percentage is clustered on wrong item for either the question or reason. This indicates that proportional reasoning skill among students need more training and practice to enable them from acquiring it in the best way.

\subsection{Visual Thinking}

To answer the research question: "What effect does the 3DL have on developing and acquiring visual thinking by the Omani fourth graders?" the visual thinking test is applied at the end of the experiment. Then, the means, standard deviations, and Independent-Samples -t-Test are conducted to calculate the statistical significance of differences between both study groups; as shown in the Table (11). 
Table 11. Means, standard deviations, and (t) of the mean scores of the experimental and control groups posttest in the visual thinking test

\begin{tabular}{llllllll}
\hline Group & Items & $\begin{array}{l}\text { Overall } \\
\text { points }\end{array}$ & Means & SD & df & t & Sig. \\
$\begin{array}{l}\text { Experimental } \\
\text { Control }\end{array}$ & $8 \times 20$ & 160 & 130.27 & 29.13 & 51 & 3.390 & $0.001^{*}$ \\
\hline
\end{tabular}

* Significance at $(\alpha \leq 0.05)$

Table (11) shows significant differences between the mean scores of the experimental and control groups posttest in the visual thinking skills test in favor of the experimental group.

The improvement of visual thinking skills for both study groups in pre and post-test is calculated using Paired-Samples-t-Test. Findings are listed in Table (12).

Table 12. Means, standard deviations, and (t) of the mean scores of the experimental and control groups pre and posttest in the visual thinking test

\begin{tabular}{lllllll}
\hline Group & $\begin{array}{l}\text { Test } \\
\text { type }\end{array}$ & Means & SD & df & t & Sig. \\
Experiment & Pre & 114.52 & 41.18 & 26 & 2.37 & $\mathbf{0 . 0 2 5 *}$ \\
al & Post & 129.67 & 29.99 & & & \\
& Pre & 100.15 & 27.27 & 26 & 0.48 & $\mathbf{0 . 6 3 8}$ \\
Control & Post & $\mathbf{1 0 2 . 4 8}$ & $\mathbf{3 0 . 4 9}$ & & & \\
\hline
\end{tabular}

* Significance at $(\alpha \leq 0.05)$

Table (12) shows there are significant differences between the mean scores of the experimental group in the visual thinking skills in favor of the post application. It is noted that there is no statistical significant differences between the mean scores of the control group in pre and post application.

To identify the effect size of using 3DL on visual thinking skills acquisition improvement of the experimental group's students, $\eta 2$ using the equation $\eta 2=\mathrm{t} 2 /(\mathrm{t} 2+\mathrm{df})$, was calculated; where ( $\mathrm{t})$ is the value of ( $\mathrm{t})$ of the overall sum, and (df) is the degrees of freedom; as shown in Table (13).

Table 13. ( $\eta 2$ ) value and the effect size of using 3DL on the visual thinking skills acquisition of the experimental group

\begin{tabular}{llll}
\hline $\begin{array}{l}\text { Independent variable } \\
\text { Using 3DL }\end{array}$ & Dependent variable & $\boldsymbol{\eta}^{2}$ & Effect size \\
& $\begin{array}{l}\text { Visual thinking skills acquisition } \\
\text { improvement }\end{array}$ & $\mathbf{0 . 1 7 8}$ & large \\
\hline
\end{tabular}

Table (13) shows that the effect size of using 3DL for the study sample is large. Eightreen percent of the total variation of the dependent variable (visual thinking skills acquisition improvement levels) is due to the effect of the independent variable (using the $3 \mathrm{DL}$ ). This percentage is higher than the one set by Cohen (15 percent or more), in order to consider the effect size of the independent variable on the dependent variable as large.

\section{Discussion}

Findings show statistically significant differences in student achievement in favor of the group that studied using the 3DL with large effect size, in knowledge and metacognitive abilities levels. The above findings are partially substantiated by the reviewed literature (Al-Mutairi, 1998; Al-Anzi, 2003; Al-Qarni, 2006; Al-Shannaq et al., 2004; Al-Khalaf, 2005; Al-Radi, 2008).

Findings show that there is an agreement among the members of the sample regarding the importance of 3DL with positive attitude towards it. In addition, there are significant differences between the mean scores of the experimental and control groups posttest in the attitudinal scale towards 3DL in favor of the experimental group. The above findings are corroborated in the literature (Al-Shaiey, 2006; Shabbat, 2005; Al-Balushi; 2009).

There is an improvement in logical thinking skills for both experimental and control groups, but the degree of improvement of the experimental group students increases better than the control group students as a result of their learning using the 3DL. Findings also show statistical differences between the growth rates in the means of the experimental and control groups, where the logical thinking skills growth rate of the experimental group is higher than the growth rate of the control group. The works of Redha (2010) and Ahmad (2010) confirm the above findings.

Findings also show significant differences between the mean scores of the experimental and control groups posttest in the visual thinking skills test in favor of the experimental group with large effect size of using 3DL for the study sample. Redha (2010) and Ahmad (2010) substantiate the above findings. 


\subsection{Conclusions and Recommendations}

We conduct this study to measure the effectiveness of the 3DL on Omani students' acquisition of practical abilities and skills. Using four research tools in a Pre-Post Test Control Group Design, findings show statistically significant differences in student achievement in favor of the experimental group. The results show students' attitudes are positive towards using 3DL in teaching. Improvements in logical and visual thinking are also observed. The authors recommend that 3DL to be used in Omani schools and emphasize the need to conduct more research on different types of virtual labs in science education at higher education institutions.

\section{Acknowledgements}

The authors would like to express their sincere appreciation to The Research Council (TRC) in Oman for their financial support of this project (TRC no. ORG/EHR/12/005) and to different research assistants and teachers who provided help during the research.

\section{References}

Ahmad, A. (2010). The effect of using a 3DL on the physics concepts achievement, acquisition of higher-order thinking skills and motivation toward science learning among students of the third preparatory class, Scientific Journal of Education, 13(6), 1-46, Egypt.

Al Musawi, A., Ambusaidi, A., Al-Balushi, S., \& Al-Balushi, K. (2015). Effectiveness of 3DL Use in Science Teaching at the Omani Schools, Paper presented at the Multidisciplinary Academic Conference on Education, Teaching and E-learning August 7-8, 2015 (MAC-ETeL 2015), Prague, Czech Republic.

Al-Anzi, H. (2003). The impact of using online science educational unit on the achievement of second preparatory class students, unpublished M.A. thesis, King Saud University, Saudi Arabia.

Al-Balushi, K. (2009). The effectiveness of chemistry 3DL on the development of practical skills and achievement of students at the post basic education in the Sultanate of Oman and their attitudes toward it, unpublished M.A. thesis, Institute of Arab Research and Studies, Egypt.

Al-Balushi, S. M., \& Al-Hajri, S. (2014). Associating animations with concrete models to enhance students' comprehension of different visual representations in organic chemistry. Chemistry Education Research and Practice, 15, 47-58. https://doi.org/10.1039/C3RP00074E

Al-Bayati, M. (2006). practical and applied dimensions of e-learning, International Network of Open and Distance Learning, Amman, Jordan.

Al-Hadhrami, A., \& Ambusaidi, A. (2012). The relationship between logical thinking and understanding of genetic concepts by grade twelve students in Oman. Al-Najah University Journal, 26(4), 959-996.

Al-Khalaf, T. (2005). The effect of using the dry and wet laboratory in teaching chemistry on the achievement of the basic ninth class students and the performance of their learning processes skills, unpublished M.A. thesis, Yarmouk University, Jordan.

Al-Mutairi, S. (1998). The impact of using science computer software on the achievement of sixth grade students, unpublished M.A. thesis, King Saud University, Saudi Arabia.

Al-Qarni, M. (2006). The impact of using computer simulation in teaching science on scientific concepts achievement among students of Bisha governorate second preparatory class. Unpublished M.A. thesis, King Khalid University, Saudi Arabia.

Al-Radi, A. (2008). The effect of using virtual laboratories technology in chemistry on the achievement of the third secondary class students of Qaseem region. Unpublished M.A. thesis, King Saud University, Saudi Arabia.

Al-Shahri, A. (2009). The effect of using virtual labs on laboratory experiments skills acquisition in biology course for Jeddah third secondary class students. Unpublished Ph.D., Um Al-Qura University, KSA.

Al-Shaiey, F. (2006). Status of using computerized science labs at secondary stage and teachers/students' attitudes towards them. Journal of Educational Sciences and Islamic Studies, 19(1), 448-460.

Al-Shannaq, Q., Abu, H. I., \& Al-Bawab, A. (2004). The impact of using the dry laboratory strategy on the achievement of science students at the University of Jordan, Educational Sciences Studies, 31(2), 318-377, Jordan.

Coble, A., Smallbone, A., Bhave, A., Watson, R., Braumann, A., \& Kraft, M. (2010). Delivering authentic experiences for engineering students and professionals through 3DLs, Proceedings of Education Engineering (EDUCON), 2010 IEEE Conference, 1085-1090, Accessed: 4.7.20214, At:

http://www.lila-project.org/resources/Documents/files/Coble_et_al_Delivering_authentic_experiences.pdf 
Farooq, M., Khlad, H., \& Ali, U. (2013). LMS and Virtual Labs for Engineering Education, Academy of Contemporary Research Journal, II(IV), 171-174.

Hatherly, P. (n. d.). The 3DL and interactive screen experiments, the Open University, Retrieved: 24.6.2014, Accessed At: https://web.phys.ksu.edu/icpe/Publications/teach2/Hatherly.pdf

ICSU (2011). Report of the ICSU, Ad-hoc Review Panel on Science Education. International Council for Science, Paris, Accessed: 30.5.2014, At: http://www.icsu.org/publications/report.pdf

Redha. H. (2010). Effective use of 3DL for enquiry and demonstration in teaching chemistry on the development of scientific thinking, Journal of Science Education, 13(6), 61-106, Egypt.

Saleh, A., Al-Hadi, M., \& Al-Qadhi, R. (2004). The Effectiveness of computer simulation programs on the achievement and laboratory skills acquisition of students at the secondary level, College of Normal Education, Cairo, Egypt.

Shabbat, M. (2005). The effectiveness of electronic computerized training and its adequacy on some biology laboratory experiments in the second secondary class of Daraa province and its impact on student achievement and their attitudes towards it. Unpublished M.A. thesis, Damascus University, Syria.

Shaheen, J., \& Khattab, K. (2005). School Lab and Its Role in Science Instruction, Usra Publishing, Amman, Jordan.

Sharples, M., Amedillo, S., Milrad, M., \& Vavoula, G. (2009). Mobile learning: small devices, big issues. In: Balacheff, N.; Ludvigsen, S.; Jong, T. de and Barnes, S. eds. Technology Enhanced Learning: Principles and Products. Heidelberg, Germany: Springer, 233-249. https://doi.org/10.1007/978-1-4020-9827-7_14

Zaitun, K. (2002). Educational Technology in Information and Communication Era, Alam Al-Kutub, Cairo, Egypt.

\section{Copyrights}

Copyright for this article is retained by the author(s), with first publication rights granted to the journal.

This is an open-access article distributed under the terms and conditions of the Creative Commons Attribution license which permits unrestricted use, distribution, and reproduction in any medium, provided the original work is properly cited. 